\title{
The novel mTOR inhibitor CCl-779 (temsirolimus) induces antiproliferative effects through inhibition of mTOR in Bel-7402 liver cancer cells
}

\author{
Shuyu Li ${ }^{\dagger}$, Yan Liang ${ }^{\dagger}$, Manlin Wu, Xiaojing Wang, Haixia Fu, Yuhao Chen and Zhigang Wang ${ }^{*}$
}

\begin{abstract}
Background: Liver cancer is one of the most frequent cancers in the world. Targeted therapy of cancer with specific inhibitors is developing and has shown promising antitumor efficacy. CCl-779 (temsirolimus), a specific inhibitor of mTOR (mammalian target of rapamycin), can block the mTOR signaling pathway. Here, we systematically examined the expression of MTOR and its downstream targets in liver cancer cells and normal liver cells, then investigated inhibitory effects of CCl-779 on mTOR signaling pathway and its role in regulating liver cancer cell growth.
\end{abstract}

Methods: The expression of mTOR and its downstream targets in Bel-7402 liver cancer cells and HL-7702 normal liver cells were examined by western blot. The mTOR specific inhibitor (CCl-779) was used to treat Bel-7402 cells to identify its effects on Bel-7402 cell growth and activity of mTOR signaling pathway in vitro. Cell viability tests were performed after the treatment of CCl-779. Western blot was applied to assess the changes of mTOR pathway and flow cytometry was used to analyze cell cycle of Bel-7402 cells after the treatment of CCl-779.

Results: mTOR, p70S6K, S6, and 4EBP1 were overexpressed in Bel-7402 cells compared with HL-7702 cells. Bel-7402 cells were sensitive to CCl-779. The survival rate of the cells treated with CCI-779 over $0.312 \mu \mathrm{M}$ was significantly different compared with that of control $(P<0.05)$. CCl-779 inhibited the phosphorylation of mTOR (Ser2448), p70S6K (Thr389), S6 (Ser240/244), and 4EBP1 (Thr37/46) in different grades and the expressions of p70S6K, S6, and 4EBP1. As a result, $\mathrm{CCl}-779$ induced a dose-dependent decrease in cell proliferation, G1/S arrest and damage of cell shape.

Conclusions: Taken together, these data showed that CCl-779 can inhibit mTOR signaling and proliferation in Bel7402 liver cancer cells in vitro. It offers a therapeutic intervention through inhibition of mTOR as a potential strategy for liver cancer.

Keywords: CCI-779 (temsirolimus), mTOR signaling, Cell growth, Liver cancer cell

\section{Background}

Liver cancer is the sixth most common cancer worldwide and the third leading cause of cancer-related death; $55 \%$ of cases are in China [1]. Rates of liver cancer in men are typically 2 to 4 times higher than in women [2]. One of the current treatments for liver cancer is liver transplantation. Surgical resection of liver cancer is associated with a high rate of recurrence [3], due to occult metastases that might exist in the remnant liver at the time of resection or as a result of the 'field' effect in the remnant liver [4]. Thus, new

\footnotetext{
* Correspondence: Iswzg@imu.edu.cn

tEqual contributors

College of Life Science, Inner Mongolia University, Hohhot, 010021, P.R. China
}

therapeutic strategies are needed due to the poor prognosis of patients with liver cancer. Targeting cancers with specific inhibitors is a developing strategy and has shown promising antitumor efficacy.

Increasing knowledge of the signal transduction pathways of growth factors has implicated them as novel targets for cancer therapy. Mammalian target of rapamycin (mTOR) is an evolutionarily conserved protein kinase that belongs to the phosphatidylinositol kinase-related kinase (PIKK) family and functions as a serine/threonine kinase. Mounting evidence has indicated that mTOR and its downstream targets S6K1 and 4EBP1 are linked to tumorigenesis. These proteins are often overexpressed or mutated in various cancers 
and promote malignant transformation [5]. Thus, inhibition of mTOR signaling is a promising therapeutic anti-cancer strategy.

Rapamycin, the naturally occurring inhibitor of mTOR, and several recently developed rapamycin analogs (RAD001, CCI-779, AP23576, AZD8055) [6,7] inhibit the growth of cell lines that have been derived from many tumor types in vitro and tumor models in vivo [8]. CCI779 , a dihydroxymethyl propionic acid ester of rapamycin, or temsirolimus, is an effective inhibitor of mTOR. Several groups have studied its suppression of various cancers [9-11], and others have initiated a phase II study of CCI779 in breast cancer [12] and glioblastoma multiforme [13]. The clinical function of RAD001 has been studied [14], but the inhibitive effects and therapeutic value of CCI-779 in liver cancer remains unclear.

In this study, we analyzed the differences in mTOR expression between liver cancer and normal liver cells and treated Bel-7402 liver cancer cells with CCI-779 to show mTOR signaling has an important role in liver cancer cell growth regulation. Our data showed the inhibitive effects of CCI-779 on mTOR signaling and liver cancer cell growth. It offers a therapeutic intervention through inhibition of mTOR as a potential strategy for liver cancer.

\section{Results and Discussion}

CCI-779 inhibits proliferation of Bel-7402 liver cancer cells

The effects of CCI-779 on cell proliferation of Bel-7402 liver cancer cells were examined by trypan blue exclusion assay. Bel-7402 cells were sensitive to CCI-779, and the survival rate of the cells treated with CCI-779 over $0.312 \mu \mathrm{M}$ was significantly suppressed compared with that of control. There was no significant difference between cells that were treated with $1 \%$ DMSO and the control (Figure 1A). As shown in the growth curve in Figure 1B, $1 \mu \mathrm{M}$ CCI-779 suppressed Bel-7402 growth from 4 to 8 days after treatment.

To determine the inhibitory effects of CCI-779 on cell growth and optimize its concentration for subsequent experiments, we calculated the half maximal inhibitory concentration $\left(\mathrm{IC}_{50}\right)$ of CCI-779 in liver cancer cells. Bel-7402 cells were treated with various concentrations of CCI-779 $(0.25 \mu \mathrm{M} \sim 28 \mu \mathrm{M})$ for $48 \mathrm{~h}$, and their susceptibility to CCI779 was determined by MTT assay. The $\mathrm{IC}_{50}$ of CCI-779 on Bel-7402 cells was $8.62 \mu \mathrm{M}$ (Figure 2).

\section{mTOR, p70S6K, S6, and 4EBP1 are overexpressed in Bel-7402 cells}

To examine the expression of mTOR and its downstream targets in Bel-7402 cells, we performed western blot analysis. As shown in Figure 3, the expression of mTOR, p70S6K, S6, and 4EBP1 was higher in Bel-7402 cells than in HL-7702 cells. The phosphorylation of these signaling proteins was also greater in Bel-7402 versus HL-7702 cells.

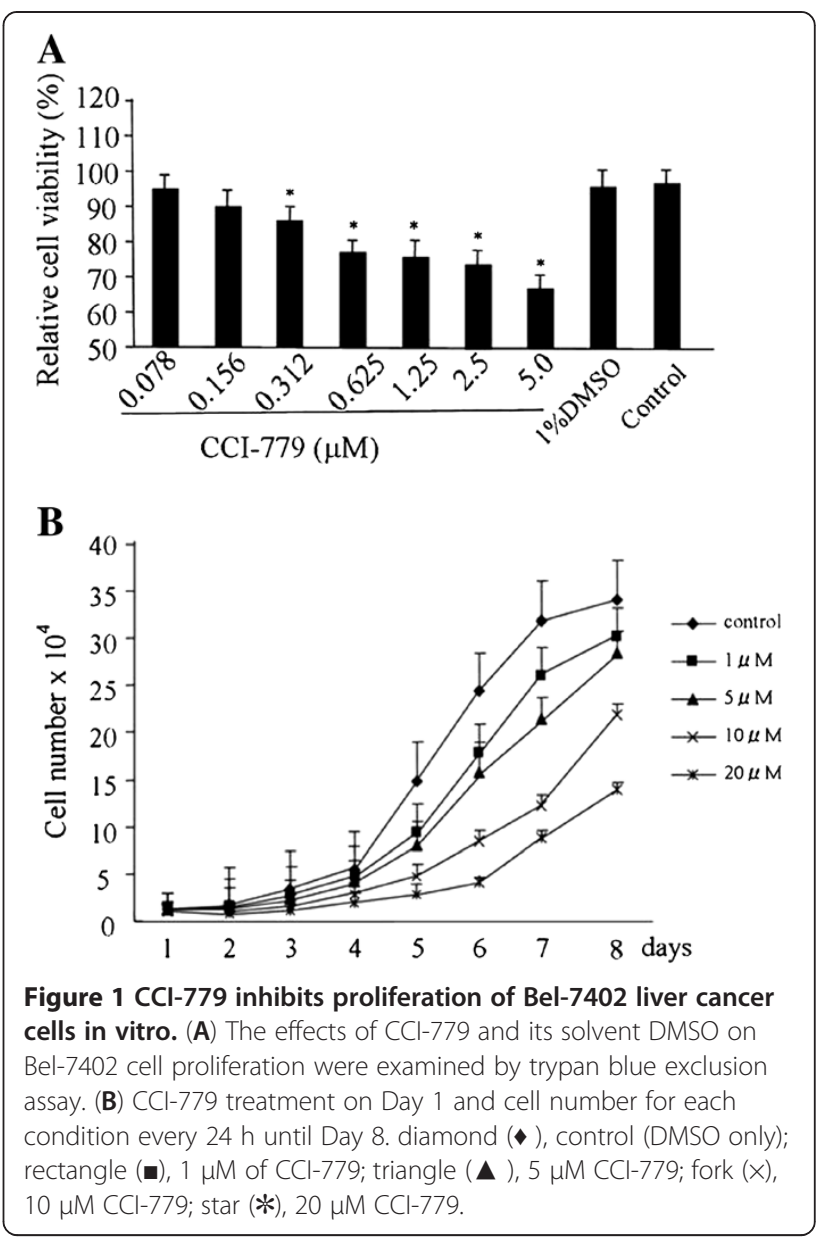

CCI-779 inhibits activation of mTOR and its downstream targets

To determine the mechanism of CCI-779 inhibition in Bel-7402 cells, we examined the activities of proteins in the mTOR signaling pathway by western blot. They were: mTOR and phospho-mTOR (Ser2448), downstream target p70S6K and p-p70S6K(Thr389), S6 and phospho-S6 (Ser240/244), 4EBP1 and p-4EBP1(Thr37/46). As shown in

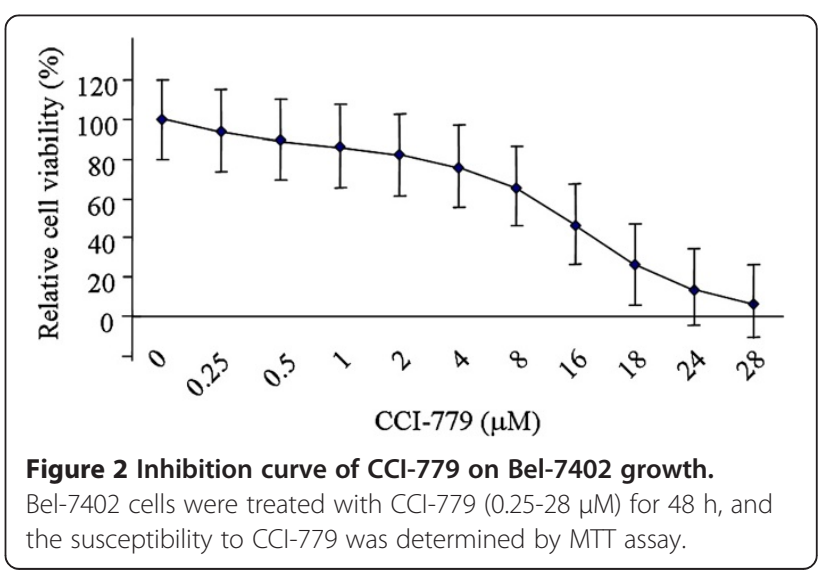



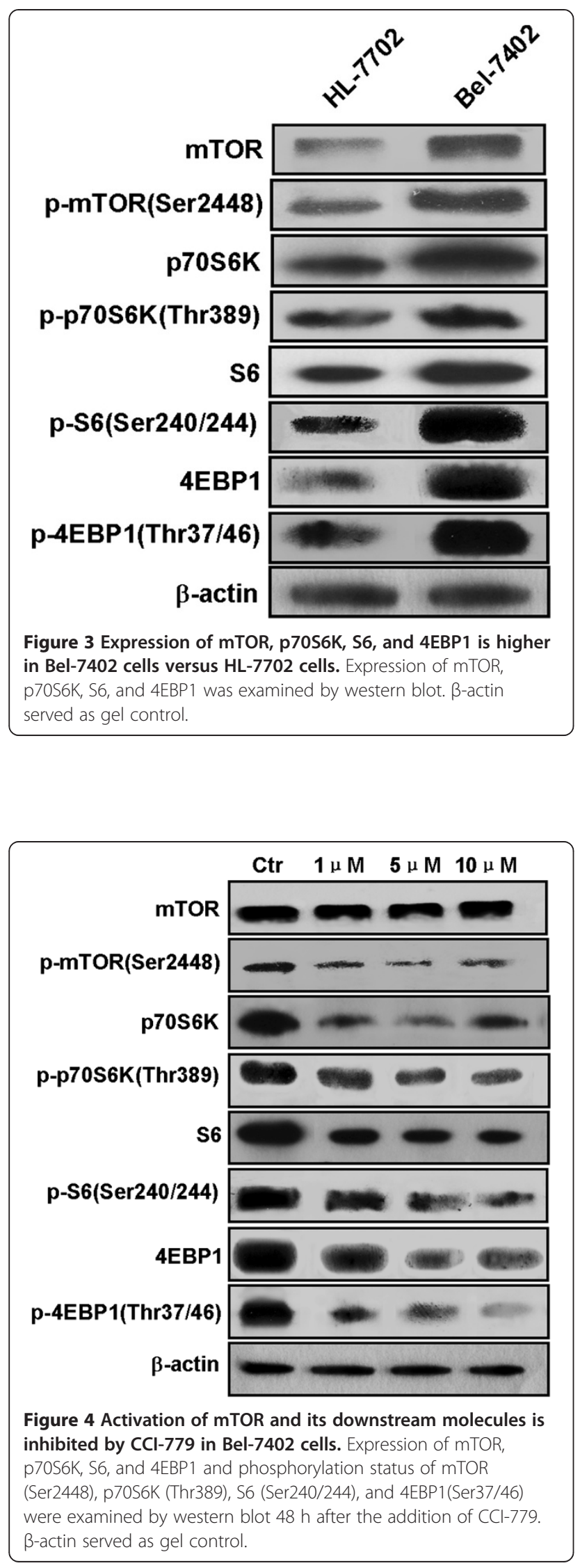

Figure 4, CCI-779 inhibited the phosphorylation of mTOR, p70S6K, S6 and 4EBP1, and slightly suppressed the expressions of mTOR, p70S6K, 4EBP1 and S6 in Bel-7402 cells.

CCI-779 induced $\mathrm{G}_{1} / \mathrm{S}$ cell-cycle arrest in Bel-7402 cells To examine the effects of CCI-779 on cell cycle, Bel7402 cells were incubated with $5 \mu \mathrm{M}$ CCI-779 for $48 \mathrm{~h}$ and analyzed by flow cytometry. An inhibition of cellcycle progression occurred as a result of CCI-779 treatment, as demonstrated by a decreased proportion of cells in $S$ phase (Figure 5). These results indicate that CCI-779 can induce G1/S cell cycle arrest in Bel-7402 liver cancer cells.

Morphological changes in Bel-7402 cells after CCl-779 treatment

mTOR is a central regulator of cell growth. With regard to lethality, we determined the effects of CCI-779 $(0.1 \sim 20 \mu \mathrm{M})$ treatment for 24 and $48 \mathrm{~h}$ on Bel-7402 cells. At concentrations of CCI-779 $\geq 1 \mu \mathrm{M}$, cell density decreased and dead cells were observed (Figure 6).

Conventional therapeutic approaches for tumors include surgery, radiation, and chemotherapy. There has been much recent progress in the development of preventive and therapeutic strategies that target molecules in signal transduction pathways of cell proliferation, migration, and invasion in tumors [15-17]. Many specific inhibitors have been identified and are beginning to be

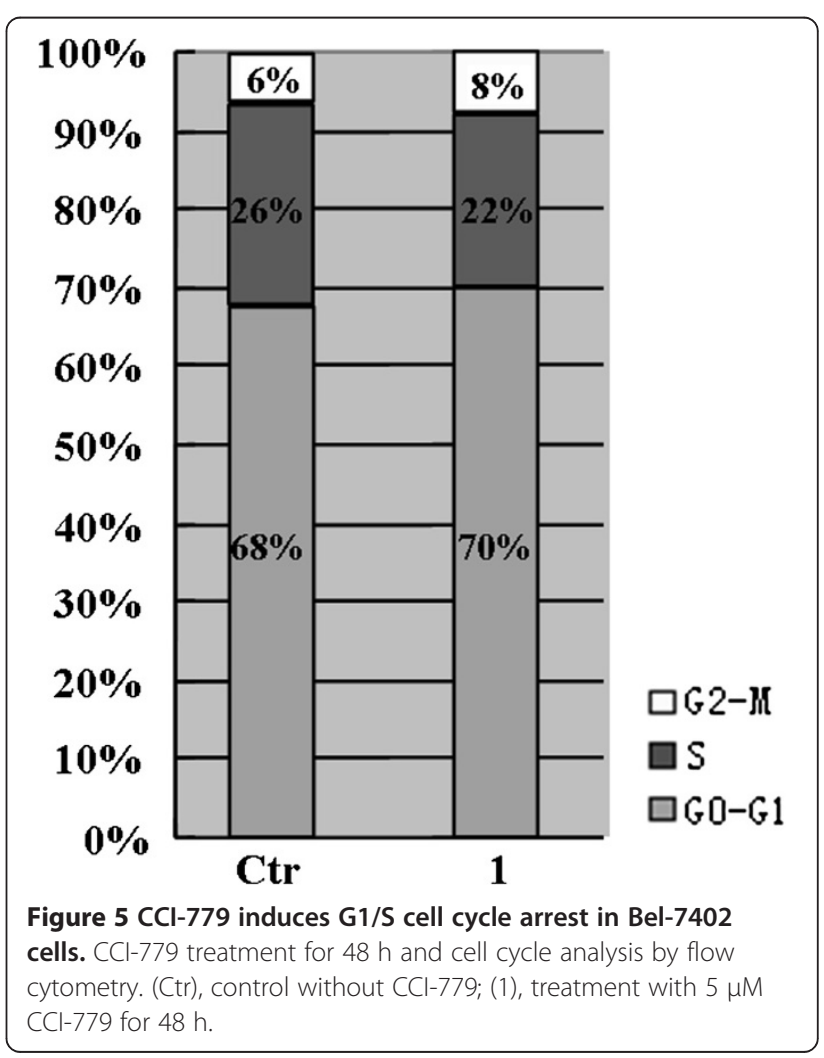


used in clinical trials for cancer. CCI-779 has antiproliferative effects against a variety of human tumorderived cell lines $[4,9,11,16,18]$ and has a good safety profile in clinical trails $[12,13,19]$.

We examined the expression of mTOR in Bel-7402 liver cancer cells and HL-7702 normal liver cells by western blot. Consistent with previous data, mTOR levels were elevated in liver cancer cells versus normal liver cells. Further, 4EBP1, p70S6K, and S6 were also overexpressed. Rictor, which complexes with mTOR, is highly expressed in liver cancer [20]. These data indicate that the components of the mTOR pathway are upregulated in tumor cells.

Treatment of Bel-7402 cells with CCI-779 does not affect the phosphorylation of mTOR, p70S6K, or S6 after short (30 $\mathrm{min}$ ) stimulations [4]. However, we observed that the phosphorylation of mTOR, p70S6K, 4EBP1 and S6 were inhibited after $48 \mathrm{~h}$ of treatment with CCI-779. Our data show that CCI-779 affects the activity of mTOR signaling pathway has a time-dependent manner in liver cancer cells. Meanwhile, the expression of p70S6K, 4EBP1 and S6 were

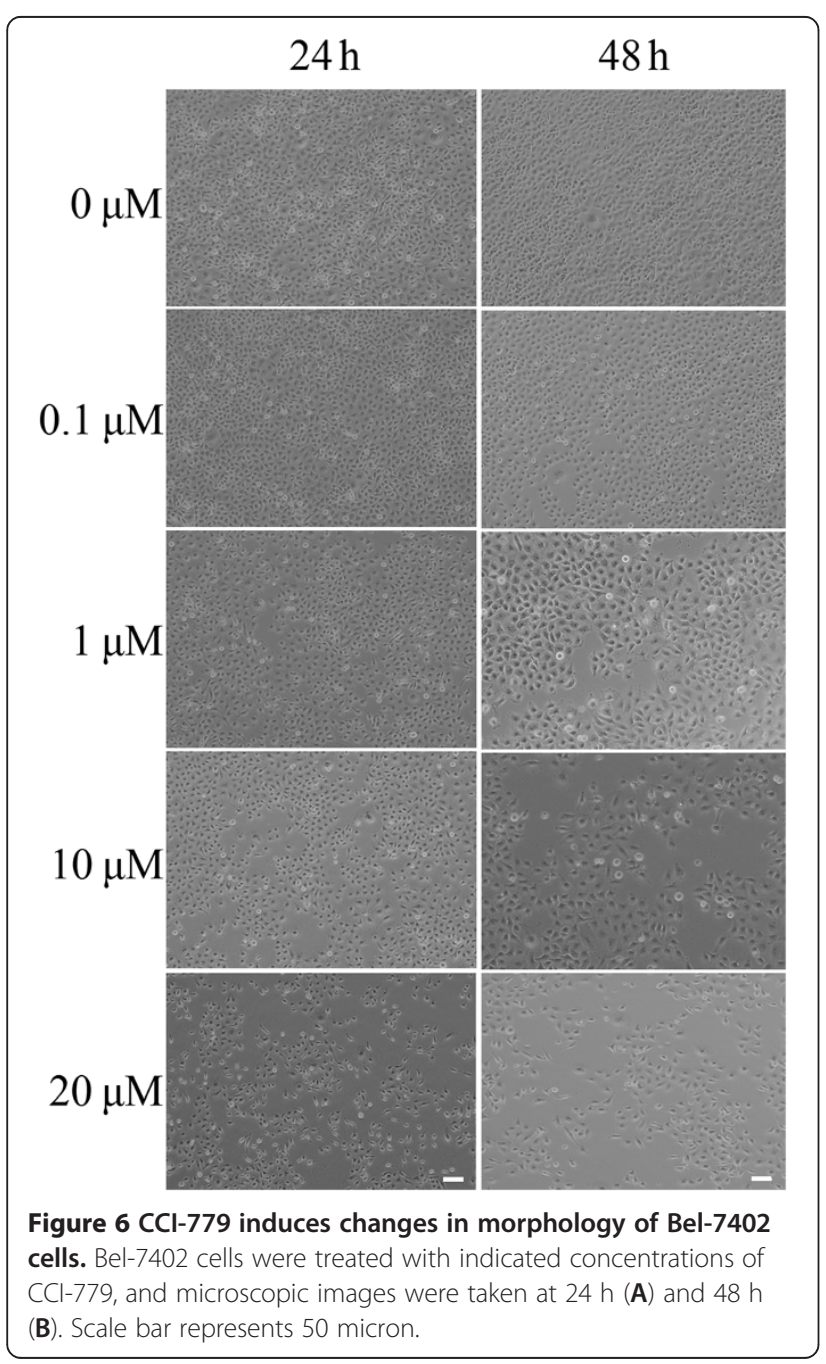

inhibited after $48 \mathrm{~h}$ of treatment with CCI-779. Similar results also were found in our previous studies on esophageal tumor cells [21] and other groups [22,23]. The activity of S6 and 4EBP1 will decreased when mTOR was inhibited by its inhibitors, and then resulting in reduced protein synthesis, but the precise mechanism is unclear now. It is believed that the reduced expression of mTOR, 4EBP1 and S6 will inhibit cell proliferation.

Further, epigenetic mechanisms also govern the development of liver cancer. Several groups have found that histone deacetylase and microRNA mediate the pathogenesis of liver cancer [24,25]. These data demonstrate the importance of the mTOR signaling pathway in regulating cancer cell proliferation. Targeting proteins in the mTOR signal pathway might be a more effective approach in developing new drugs. For example, FKBP38 is a key regulator of mTOR. The binding of FKBP38 to mTOR inhibits the mTOR pathway; but Rheb can suppress FKBP38 and hence releases the growth signals [26]. These discoveries provide more targets in studying the inhibitors of the mTOR pathway and novel targets for cancer therapies.

mTOR has been proposed to regulate the basic process as a central regulator of cell growth [27], and there is a relationship between disorganization of the mTOR pathway and tumors $[28,29]$. In a previous study, we demonstrated that another clinical analog of rapamycin, RAD001, inhibits the growth of esophageal cancer cells in vitro [21]. Several studies have reviewed mTOR signaling in liver cancer and the occurrence of tumors, therapy, and the design of antitumor drugs [30,31]. The combination of two or more inhibitors has been proposed to enhance their effects on tumor suppression. Yet, attempts to combine two inhibitors [32] have not been efficacious. Recent years, transgenic mouse models in the development and progression of liver cancer was developed [33,34]. Undoubtedly, it will be a powerful tool that can be used to study liver cancer. Although rapamycin and its analogs are well established as anticancer drugs, new inhibitors of mTOR signaling must be identified and designed.

\section{Conclusions}

In conclusion, our results demonstrate the importance of the mTOR signaling pathway in regulating liver cancer cell proliferation. CCI-779 has inhibitory effects on Bel-7402 liver cancer cells by suppressing the activity of mTOR and its downstream components. Thus, inhibition of mTOR is a potential therapeutic strategy for liver cancer.

\section{Materials and methods}

\section{Cell lines and culture conditions}

Bel-7402 human liver cancer cells were grown in 1640 medium, supplemented with $10 \%$ heat-inactivated fetal 
bovine serum. HL-7702 normal liver cells were maintained in 1640 medium, supplemented with $20 \%$ heat-inactivated fetal bovine serum. All cell lines were cultured in $5 \% \mathrm{CO}_{2}$ at $37^{\circ} \mathrm{C}$.

\section{Reagents}

CCI-779 (temsirolimus), a derivative of rapamycin, was synthesized by Selleck Chemicals LLC (Huston, USA) and dissolved in DMSO (Sigma Chemical Corp., St. Louis, MO). The concentration of DMSO in the final solution did not exceed $1 \%(\mathrm{v} / \mathrm{v})$.

\section{Trypan blue exclusion assay of cell proliferation}

The antiproliferative effects of CCI-779 on Bel-7402 cells in culture were measured by trypan blue exclusion assay. Bel-7402 cells were used to seed 24-well culture plates at $1 \times 10^{4}$ per well $24 \mathrm{~h}$ before drug treatment. For sensitivity experiments, subconfluent cells were treated with various concentrations CCI-779 $(0.078 \mu \mathrm{M}, 0.016 \mu \mathrm{M}$, $0.312 \mu \mathrm{M}, 0.625 \mu \mathrm{M}, 1.25 \mu \mathrm{M}, 2.5 \mu \mathrm{M}$, and $5.0 \mu \mathrm{M})$ and $1 \%$ DMSO (v/v) for $48 \mathrm{~h}$; harvested with trypsin; and stained with trypan blue. Cell number was counted using a hematocytometer.

For growth curve experiments, subconfluent cells were treated with various concentrations of CCI-779 $(1 \mu \mathrm{M}$, $5 \mu \mathrm{M}, 10 \mu \mathrm{M}$, and $20 \mu \mathrm{M}$ ) for $48 \mathrm{~h}$, harvested with trypsin on the indicated day after treatment, and stained with trypan blue. Cell number was counted using a hematocytometer.

\section{MTT assay and $\mathrm{IC}_{50}$ calculation}

Exponentially growing cells were used to seed 96-well plates at $4 \times 10^{3}$ cells per well $48 \mathrm{~h}$ before drug treatment. Then, cells were incubated with CCI-779 at various concentrations $(0.25 \mu \mathrm{M}, 0.5 \mu \mathrm{M}, 1.0 \mu \mathrm{M}, 2.0 \mu \mathrm{M}, 4.0 \mu \mathrm{M}$, $8.0 \mu \mathrm{M}, 16.0 \mu \mathrm{M}, 18.0 \mu \mathrm{M}, 24.0 \mu \mathrm{M}$, and $28.0 \mu \mathrm{M}$ ) for $48 \mathrm{~h}$. The medium with CCI-779 was absorbed, and fresh medium was added. 3-(4,5-dimethylthiazol-2-yl)2,5-diphenyltetrazolium bromide (MTT, 5 g/l; SigmaAldrich, USA) was added to each well and incubated for $4 \mathrm{~h}$ at $37^{\circ} \mathrm{C}$. The solution was absorbed, and formazan product was dissolved by adding $100 \mu \mathrm{l}$ DMSO to each well and incubated it for $10 \mathrm{~min}$ at $37^{\circ} \mathrm{C}$. MTT absorbance was measured at $490 / 630 \mathrm{~nm}$ with a spectrophotometer set (Thermo, Multiskan SX 353, USA). $\mathrm{IC}_{50}$ was calculated by Logit model, based on the data.

\section{Cell cycle analysis by flow cytometry}

Bel-7402 cells were plated in 6-well tissue culture plates at $3 \times 10^{5}$ cells per well and incubated for $48 \mathrm{~h}$ at $37^{\circ} \mathrm{C}$. For cell cycle analysis, subconfluent cells were treated with $5 \mu \mathrm{M}$ CCI-779 for $48 \mathrm{~h}$ and harvested. Cells were washed with cold PBS and stained with $50 \mathrm{mg} / \mathrm{L}$ propidium iodide (PI,
Sigma-Aldrich, USA). DNA content was analyzed by flow cytometry (FACS Calibur, Becton-Dickinson Co., USA).

\section{Cell shape assay}

Bel-7402 cells were used to seed 6-well culture plates at $3 \times 10^{5}$ per well $24 \mathrm{~h}$ before drug treatment. Cells were treated with various concentrations of CCI-779 (0.1, 1, 10 , and $20 \mu \mathrm{M})$ for 24 and $48 \mathrm{~h}$ and imaged with a digital camera that was mounted on a light microscope (Olympus DP-70, Japan).

\section{Western blot analysis}

Bel-7402 cells were plated in 6 -well plates at $3 \times 10^{5}$ per well and incubated for $24 \mathrm{~h}$ in medium. On the following day, cells were treated with various concentrations of CCI-779 $(1 \mu \mathrm{M}, 5 \mu \mathrm{M}$ and $10 \mu \mathrm{M})$ for $48 \mathrm{~h}$ and dissolved in cell lysis buffer (Thermo, USA). The concentrations of protein lysates were measured by Bio-Rad protein determination method (Bio-Rad, CA, USA).

Equal amounts $(40 \mu \mathrm{g})$ of protein were electrophoresed in SDS-polyacrylamide gels, transferred to Immun-Blot ${ }^{\mathrm{TM}}$ PVDF membranes (Bio-RAD, CA, USA), and incubated with primary antibodies overnight at $4^{\circ} \mathrm{C}$ and peroxidaselinked secondary antibodies at room temperature for $1 \mathrm{~h}$. Enhanced chemiluminescence (ECL) (GE Healthcare, UK) was used to detect the signals. The primary antibodies were against mTOR, phosphor-mTOR (Ser2448), phosphor-p70S6K (Thr389) (Abcam, UK); S6, phosphor-S6 (Ser240/244), phosphor-4EBP1 (Thr37/46) (Cell Signaling Technology, Inc., MA, USA); p70S6K, 4EBP1 (Santa Cruz Biotechnology, Inc., CA, USA), and $\beta$-actin (Sigma-Aldrich, USA).

\section{Statistical analysis}

Descriptive statistics were generated for all quantitative data and expressed as mean \pm SD. Proliferation of cells that were exposed to the drugs was compared with that of the negative control. Statistical significance was defined as " $\mathrm{p}<0.05$.

\section{Abbreviations}

mTOR: Mammalian target of rapamycin; S6: Ribosomal protein S6; p7056K: p70 ribosomal S6 kinase; 4EBP1: Eukaryotic translation initiation factor 4E-binding protein 1; IRS1: Insulin receptor substrate-1; PBS: Phosphate-buffered saline; SDS: Sodium dodecylsulfate.

\section{Competing interests}

The authors declare that they have no competing interests.

\section{Authors' contributions}

ZW, SL and YL conceived and designed the study. SL and YL drafted the manuscript. SL, YL, MW, XW, HF and YC performed the experimental studies. All authors have read and approved the final manuscript.

\section{Acknowledgments}

This work was supported by a grant from the Natural Sciences Foundation of China (No. 31160469) and Natural Sciences Foundation of Inner Mongolia, China (No. 2011MS0521). 
Received: 28 January 2013 Accepted: 20 March 2013

Published: 28 March 2013

\section{References}

1. Jemal A, Bray F, Center MM, Ferlay J, Ward EForman D: Global cancer statistics. CA Cancer J Clin 2011, 61(2):69-90.

2. Bosch FX, Ribes J, Diaz MCleries R: Primary liver cancer: worldwide incidence and trends. Gastroenterology 2004, 127(5):S5-S16.

3. Shah SA, Wei AC, Cleary SP, Yang I, McGilvray ID, Gallinger S, Grant DRGreig PD: Prognosis and results after resection of very large $(\geq 10 \mathrm{~cm})$ hepatocellular carcinoma. J Gastrointest Surg 2007, 11(5):589-595.

4. Hui ICF, Tung EKK, Sze KMF, Ching YPNg IOL: Rapamycin and CCI-779 inhibit the mammalian target of rapamycin signalling in hepatocellular carcinoma. Liver Int 2010, 30(1):65-75.

5. Petroulakis E, Mamane $Y$, Le Bacquer O, Shahbazian D, Sonenberg N: mTOR signaling: implications for cancer and anticancer therapy. $\mathrm{Br} J \mathrm{Cancer}$ 2005, 94(2):195-199.

6. Vignot S, Faivre S, Aguirre DRaymond E: mTOR-targeted therapy of cancer with rapamycin derivatives. Ann Oncol 2005, 16(4):525-537.

7. Chresta CM, Davies BR, Hickson I, Harding T, Cosulich S, Critchlow SE, Vincent JP, Ellston R, Jones D, Sini P, James D, Howard Z, Dudley P, Hughes G, Smith L, Maguire S, Hummersone M, Malagu K, Menear K, Jenkins R, Jacobsen M, Smith GC, Guichard S, Pass M: AZD8055 Is a Potent, Selective, and Orally Bioavailable ATP-Competitive Mammalian Target of Rapamycin Kinase Inhibitor with In vitro and In vivo Antitumor Activity. Cancer Res 2010, 70(1):288-298.

8. Easton J, Houghton P: mTOR and cancer therapy. Oncogene 2006, 25(48):6436-6446.

9. Peralba JM, de Graffenried L, Friedrichs W, Fulcher L, Grunwald V, Weiss GHidalgo M: Pharmacodynamic evaluation of $\mathrm{CCl}-779$, an inhibitor of mTOR, in cancer patients. Clin Cancer Res 2003, 9(8):2887-2892.

10. Raymond E, Alexandre J, Faivre S, Vera K, Materman E, Boni J, Leister C, Korth-Bradley J, Hanauske A, Armand JP: Safety and pharmacokinetics of escalated doses of weekly intravenous infusion of CCl-779, a novel mTOR inhibitor, in patients with cancer. J Clin Oncol 2004, 22(12):2336-2347.

11. Hudes G, Carducci M, Tomczak P, Dutcher J, Figlin R, Kapoor A, Staroslawska E, Sosman J, McDermott D, Bodrogi I, Kovacevic Z, Lesovoy V, Schmidt-Wolf IG, Barbarash O, Gokmen E, OToole T, Lustgarten S, Moore L, Motzer RJ: Global ARCC Trial. Temsirolimus, interferon alfa, or both for advanced renal-cell carcinoma. N Engl J Med 2007, 356(22):2271-2781.

12. Chan S, Scheulen ME, Johnston S, Mross K, Cardoso F, Dittrich C, Eiermann W, Hess D, Morant R, Semiglazov V: Phase II study of temsirolimus (CCl-779), a novel inhibitor of mTOR, in heavily pretreated patients with locally advanced or metastatic breast cancer. J Clin Oncol 2005, 23(23):5314-5322

13. Chang SM, Wen P, Cloughesy T, Greenberg H, Schiff D, Conrad C, Fink K, Robins HI, De Angelis L, Raizer J, Hess K, Aldape K, Lamborn KR, Kuhn J, Dancey J, Prados MD: North American Brain Tumor Consortium and the National Cancer Institute. Phase II study of CCl-779 in patients with recurrent glioblastoma multiforme. Invest New Drugs 2005, 23(4):357-361.

14. Zhu AX, Abrams TA, Miksad R, Blaszkowsky LS, Meyerhardt JA, Zheng H, Muzikansky A, Clark JW, Kwak EL, Schrag D, Jors KR, Fuchs CS, lafrate AJ, Borger D, RRyan DP: Phase 1/2 study of everolimus in advanced hepatocellular carcinoma. Cancer 2011, 117(22):5094-5102.

15. Wan $X$, Helman $L$ : The biology behind mTOR inhibition in sarcoma. Oncologist 2007, 12(8):1007-1018.

16. Fasolo A, Sessa C: mTOR inhibitors in the treatment of cancer. Expert Opin Investig Drugs 2008, 17(11):1717-1734.

17. Sarkar FH, LI Y: Targeting multiple signal pathways by chemopreventive agents for cancer prevention and therapy1. Acta Pharmacol Sin 2007, 28(9):1305-1315.

18. Yu K, Toral-Barza L, Discafani C, Zhang W, Skotnicki J, Frost PGibbons J: mTOR, a novel target in breast cancer: the effect of CCl-779, an mTOR inhibitor, in preclinical models of breast cancer. Endocr Relat Cancer 2001, 8(3):249-258.

19. Buckner JC, Forouzesh B, Erlichman C, Hidalgo M, Boni JP, Dukart G, Berkenblit A, Rowinsky EK: Phase I, pharmacokinetic study of temsirolimus administered orally to patients with advanced cancer. Invest New Drugs 2010, 28(3):334-342.
20. Villanueva A, Chiang DY, Newell P, Peix J, Thung S, Alsinet C, Tovar V, Roayaie $S$, Minguez B, Sole M: Pivotal role of mTOR signaling in hepatocellular carcinoma. Gastroenterology 2008, 135(6):1972-1983.

21. Wang ZG, Fukazawa T, Nishikawa T, Watanabe N, Sakurama K, Motoki T, Hatakeyama S, Omori O, Ohara T, Tanabe S, Fujiwara Y, Takaoka M, Shirakawa Y, Yamatsuji T, Tanaka N, Naomoto Y: RAD001 offers a therapeutic intervention through inhibition of mTOR as a potential strategy for esophageal cancer. Oncol Rep 2010, 23(4):1167-1172.

22. Batista A, Barata JT, Raderschall E, Sallan SE, Carlesso N, Nadler LM, Cardoso AA: Targeting of active mTOR inhibits primary leukemia T cells and synergizes with cytotoxic drugs and signaling inhibitors. Exp Hematol 2011, 39(4):457-472.

23. Lee KH, Hur HS, Im SA, Lee J, Kim HP, Yoon YK, Han SW, Song SH, Oh DY, Kim TY, Bang YJ: RAD001 shows activity against gastric cancer cells and overcomes 5-FU resistance by downregulating thymidylate synthase. Cancer Lett 2010, 299(1):22-28.

24. Pineau P, Volinia S, McJunkin K, Marchio A, Battiston C, Terris B, Mazzaferro V, Lowe SW, Croce CM, Dejean A: miR-221 overexpression contributes to liver tumorigenesis. Proc Natl Acad Sci USA 2010, 107(1):264-269.

25. Shao H, Gao C, Tang H, Zhang H, Roberts LR, Hylander BL, Repasky EA, Ma WW, Qiu J, Adjei AA, Dy GK, Yu C: Dual targeting of mTORC1/C2 complexes enhances histone deacetylase inhibitor-mediated anti-tumor efficacy in primary HCC cancer in vitro and in vivo. $J$ Hepatol 2012, 56(1):176-183.

26. Bai $X$, Ma D, Liu A, Shen $X$, Wang QJ, Liu Y, Jiang Y: Rheb activates mTOR by antagonizing its endogenous inhibitor, FKBP38. Science 2007, 318(5852):977-980.

27. Schmelzle T, Hall MN: TOR, a central controller of cell growth. Cell 2000, 103(2):253-262.

28. Albanell J, Dalmases A, Rovira A, Rojo F: mTOR signaling in human cancer. Clin Trans/ Oncol 2007, 9(8):484-493.

29. Hidalgo M, Rowinsky EK: The rapamycin-sensitive signal transduction pathway as a target for cancer therapy. Oncogene 2000, 19(56):6680-6686.

30. Wullschleger S, Loewith $\mathrm{R}$, Hall MN: TOR signaling in growth and metabolism. Cell 2006, 124(3):471-484.

31. Shaw RJ, Cantley LC: Ras, PI (3) K and mTOR signalling controls tumour cell growth. Nature 2006, 441(7092):424-430.

32. Jiang Q, Weiss JM, Back T, Chan T, Ortaldo JR, Guichard S, Wiltrout RH: mTOR Kinase Inhibitor AZD8055 Enhances the Immunotherapeutic Activity of an Agonist CD40 Antibody in Cancer Treatment. Cancer Res 2011, 71(12):4074-4084.

33. French DM, Lin BC, Wang M, Adams C, Shek T, Hötzel K, Bolon B, Ferrando R, Blackmore C, Schroeder K, Rodriguez LA, Hristopoulos M, Venook R, Ashkenazi A, Desnoyers LR: Targeting FGFR4 inhibits hepatocellular carcinoma in preclinical mouse models. PLoS One 2012, 7(5):e36713. doi:10.1371/journal.pone.0036713.

34. Fausto N, Campbell JS: Mouse models of hepatocellular carcinoma. Semin Liver Dis 2010, 30(1):87-98.

\section{doi:10.1186/1475-2867-13-30}

Cite this article as: Li et al:: The novel mTOR inhibitor $\mathrm{CCl}-779$

(temsirolimus) induces antiproliferative effects through inhibition of mTOR in Bel-7402 liver cancer cells. Cancer Cell International 2013 13:30.

\section{Submit your next manuscript to BioMed Central and take full advantage of:}

- Convenient online submission

- Thorough peer review

- No space constraints or color figure charges

- Immediate publication on acceptance

- Inclusion in PubMed, CAS, Scopus and Google Scholar

- Research which is freely available for redistribution 